TP Periodica Polytechnica

Transportation Engineering

46(3), pp. 142-150, 2018

https://doi.org/10.3311/PPtr. 12073

Creative Commons Attribution (i)

RESEARCH ARTICLE

\section{Mathematical Modelling of the Cost Structure of the Logistics System of Shopping Malls in Budapest}

\author{
Krisztián Bóna $^{1 *}$, Ádám Róka ${ }^{1}$, Dávid Lajos Sárdi ${ }^{1}$
}

Received 18 January 2018; accepted 20 February 2018

\begin{abstract}
In this paper, we will present the examination of the city logistics system of shopping malls in Budapest. We will introduce the mathematical model of its cost structure which can help us to evaluate this complex system from a financial point of view. The data, we collected earlier, made it possible to simulate the physical processes of the current logistics system and to compare them with innovative new systems as well. However, in case of any new systems it is essential to compare the costs too. The mathematical modelling was based on the observed processes of three shopping malls in Budapest. We added this cost structure to the simulation model to make the simulation of costs possible, so now we have a tool which can help us comprehensively examine the current logistic system of the shopping malls in Budapest as well as a consolidation based proposed solution.
\end{abstract}

\section{Keywords}

logistics, city logistics, Budapest, shopping malls, cost structure, cost model, simulation

\section{Introduction}

In 2015 we started to examine the logistics system of shopping malls in Budapest with the city logistics research group of the Department of Material Handling and Logistics Systems at the Budapest University of Technology and Economics. There was no available data about the city logistics systems of shopping malls, despite the fact, that based on data from the Central Statistical Office in 2015 there were 32405 retailers in Budapest (Hungarian Central Statistical Office, 2015) and approximately 3000 of them could be found in 18 shopping malls across the city. This means that $10 \%$ of all retailers in the city are concentrated into 18 exact points. This concentration means significant savings potential, but we did not possess the data and information to make improvements possible.

First, we developed a standard research methodology which made it possible to examine the logistic characteristics of the shopping malls, because if we would like to examine the performances and costs in a system (for example, to use activity based costing principles), we need to understand and describe the processes and the activities of the examined supply chain (Grzybowska and Kovács, 2016). This methodology has an exploratory part and a descriptive part which consisted of a complex questionnaire containing questions about every logistic process of the shops (Mészáros et al., 2016). With use of this methodology we examined 327 shops from 3 shopping malls in Budapest, so we were able to gather insights from more than $10 \%$ of all shopping mall-based shops in Budapest (Mészáros et al., 2017). The results of the examinations showed us, that the surveyed shops deliver in small vehicles small quantity of goods with high frequency. The deliveries are usually during the rush hour in the morning and during the opening hour of shops. Because of the several problems we found in the system, it is worth to consider new city logistics solutions, therefore we started to model the current system's processes. We developed a mesoscopic simulation model in MS Excel which allows us to compare the logistic processes of the current logistics system of the shopping malls in Budapest (the current system can be seen on Fig. 1) and a proposed alternative solution (which can be seen on Fig. 2), where the

\footnotetext{
${ }^{1}$ Department of Material Handling and Logistics Systems,

Faculty of Transportation Engineerig and Vehicle Engineering,

Budapest University of Technology and Economics

H-1111, Budapest, Bertalan L. u. 7-9., Building L, Hungary

* Corresponding author, e-mail: krisztian.bona@logisztika.bme.hu
} 
suppliers deliver to a consolidation center, from where we can serve the shopping malls of the city (Sárdi and Bóna, 2017).

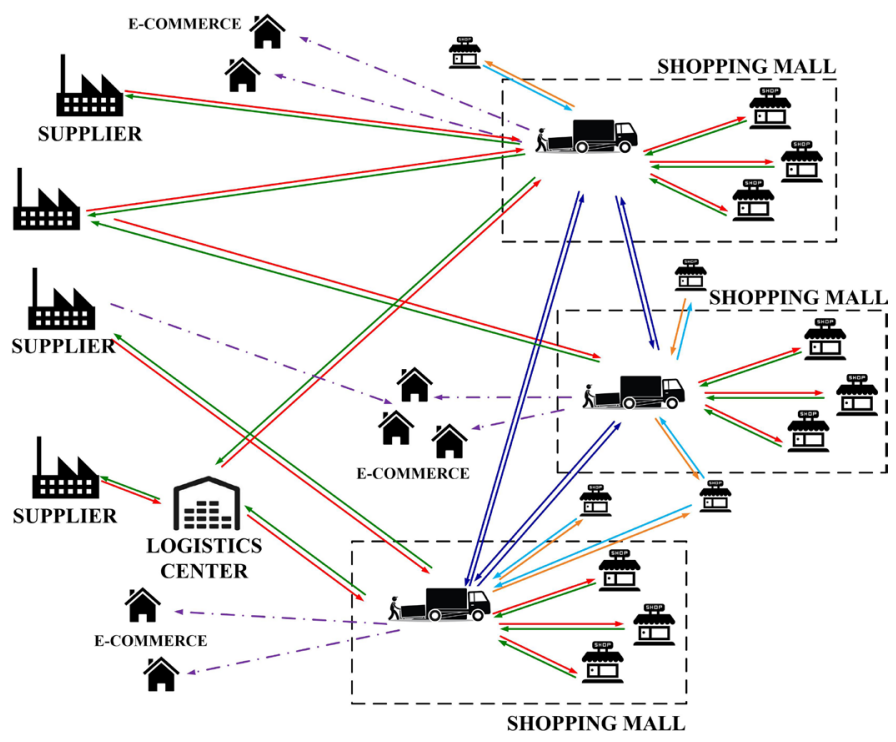

Fig. 1 The present logistics system of the shopping malls in Budapest (Sárdi and Bóna, 2017)

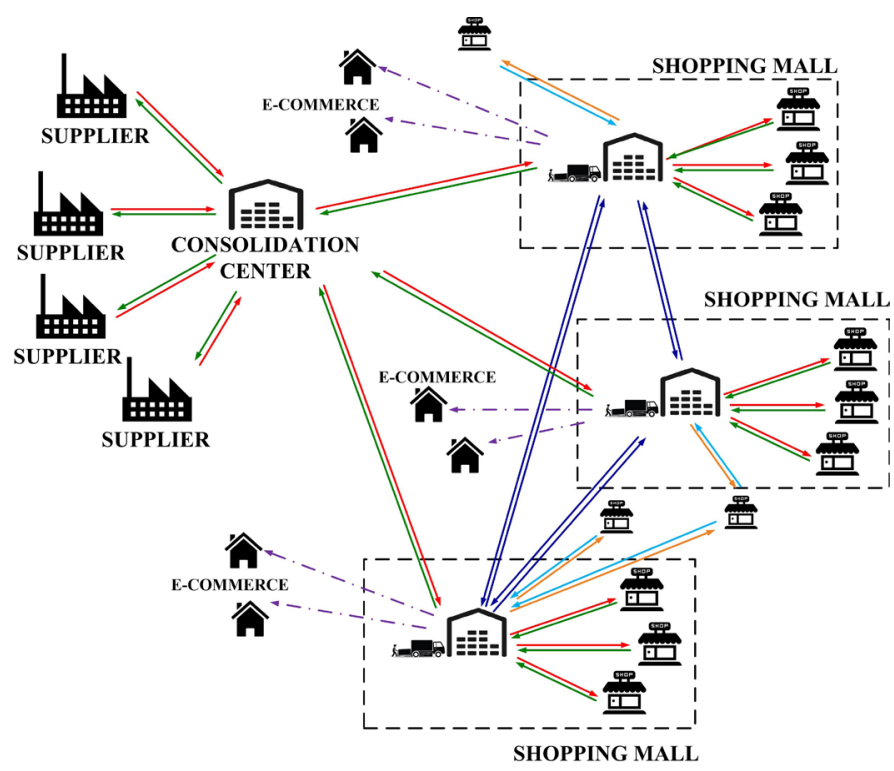

Fig. 2 Possible future logistics system of the shopping malls in Budapest (Sárdi and Bóna, 2017)

So, now the model can examine the basic parameters of the supply transactions of shopping malls, such as emission, performances and stocks, thereby quantifying the characteristics of the current system and the new system with the consolidation center. However, if we would like to improve a system, it is essential to examine the associated costs too, because without them one could hardly make an informed decision as to which system is preferable. For this reason, it is necessary to build the cost structure of the examined system and add it to the simulation model with the specific costs, so we are able to have a clear picture of the logistics costs of the current and proposed future systems.

\section{Costs in city logistics}

After our previous projects, now we know the physical parameters of the logistics system for more than 300 shops, but we do not know the specific cost parameters because that is often considered sensitive information by the shops. Another problem is that the companies do not measure the logistic and other accompanying performances (for example the delivery performance), even though it is essential to know the performance parameters to provide quality logistics services (Bokor, 2006). While measuring the specific costs, it is hard to define the logistics performances exactly, because there are no exact borders between the processes, it is difficult to separate them. For instance, an employee can take part in several different processes. In the past, with unique products the direct costs were measurable, but as a result of the complexity brought about by globalized trade this has significantly changed. Logistics systems are becoming more and more complex, so we need to examine increasingly complex networks, just like in the current case, where we analyse a highly multifaceted complex city logistics system. In these kinds of systems, it is extremely challenging to measure the performances (Duma, 2008).

Operational and logistics controlling could be a solution for the problem of measurement of performances and costs, but for them we need up to date information, which is missing in several cases (Sliwczynski, 2011). Lots of companies in the logistics system of shopping malls of Budapest do not use an own ERP system, from where they could download the required parameters. But, making appropriate decisions in the city logistics systems requires these information, and to know and analyse this information we need the controlling methodologies. When we decide, it is essential to know the logistics costs and the efficiency indicators that are calculated from the costs, but to know them we need the controlling system (Bokor, 2006). Therefore, it is also important to develop the mesoscopic simulation model to simulate the costs in this system and not only the physical parameters.

Naturally, we reviewed the existing special cost models in transportation, in logistics and even in city logistics, but the costs of this special urban logistics system have not been modelled yet. Researchers developed calculation models in transportation (Bokor, 2011) and also in logistics. They adapted the methodologies from transportation into logistics systems (Griful-Miquela, 2001), examined the logistics cost drivers (Bokor, 2010), developed the cost calculation model of logistics providers, and also have a big role in the currently examined city logistics system (Bokor, 2012).

The city logistics research group of the Department of Material Handling and Logistics Systems conducted important researches about the costs in city logistics and was able to develop a complex city logistics cost model according to a multiple-stage gateway concept (Bakos et al., 2012) while they even examined special city logistical system concepts with urban distribution centers based on the costs (Bakos, 2013). 
However, we need a cost model that describes the examined special city logistics system in a way that it can be adapted to the mesoscopic simulation model we developed.

\section{Mathematical modelling of the cost structure}

We are going to present the cost structure of the logistics system of the shopping malls in Budapest in a three-dimensional structure, where the three dimensions are the cost centers (junctions and routes in the network), the participants (the companies in the logistics system) and the processes of the logistics system. So, the items of the three-dimensional matrix will show us the costs of a given company in a given process at a given cost center. This gives us a mutually exclusive, collectively exhaustive structure, in other words if we summarize these items for the companies by processes and cost centers, it shows us the sum logistics costs of the given company in the system. If we summarize the whole matrix, it shows us the sum cost of the logistics system of the shopping malls.

In this paper, we present a simple linear cost structure, but this is only the first stage of the examination of the costs in this system. This structure helps us to review the breakdown of costs into specific ones, and the hierarchy of the specific costs is clear in this structure. In the next chapters, we are going to present the companies, the processes and the cost centers of the examined logistics system; based on them we are going to draw up the threedimensional cost structure and present the mathematical model behind it for the current and examined new logistics system too.

\subsection{Companies in the system}

There are many participants in this complex system. We can differentiate suppliers (in some cases they are logistics provider companies), transporters (logistics providers, small packet companies or possibly be the same company as the supplier), the shop operators (it can be the same company as the supplier or the transporter), the shopping mall operators (they also operate the logistics areas). Also - only in the case of the earlier presented new system - the city logistics provider companies, who operate the consolidation center and the cross docks in the shopping malls, and also handle the deliveries and the material handling tasks.

However, the companies that participate in this complex system, are not necessarily shown in the mathematical model. For example, the costs (also the logistics costs) of the shopping mall operators are paid by shop operators via the shop rent fee. The other factor is that the participants are paying also to each other, for example the shop operators pay the logistics costs of the suppliers. In the model, the costs must be showed at the particular company that makes the payment, be it a rent fee or a service fee etc., and this company is always the shop operator in this system. This means that in our cost structure the companies are always the shop operators, because ultimately, they pay every logistics cost that are generated by their supplies.

\subsection{Processes in the system}

In this system, the processes can be classified into five groups: loading processes, transport processes, storage processes (the three groups of the classic logistics processes), intralogistics operation and administration processes. Naturally, not every process exists at every participant company, so zero costs are also possible in some points in this cost structure.

\subsubsection{Loading}

First process group is loading. The subgroups are loading and unloading at the suppliers, in the logistics areas (cross docks in the new system) and in the consolidation center only in the new system.

\subsubsection{Transport}

Second process group is transport. In this group, every process can be FTL (full truck load) or LTL (less than truck load) organized. In the model, we have deliveries between suppliers and shopping malls in the current system, and deliveries between suppliers and the consolidation center and between the center and cross docks of the malls in the new system. Naturally, we have inverse deliveries (delivery of empties, return goods and service transports) between the shopping malls and suppliers in the new system, between malls and the consolidation center and between the center and suppliers in the new system.

\subsubsection{Storage}

Third process group is storage. Storage processes are present at the suppliers (in the supplier sites), in the consolidation center (only in the new system), temporary storage at the logistics area (cross docks in the new system) of the shopping mall, and in the shops (or in warehouses associated with the shops).

\subsubsection{Intralogistics operation}

Fourth process group is intralogistics operation. We have material handling between the logistics areas of shopping malls (cross docks in the new system) and the shops (or related warehouse), material handling between warehouses of the shops and shopping areas of the shops, other storage material handlings at the suppliers, in the consolidation center (only in the new system), at the logistics areas of the shopping malls (cross docks in the new system) and in the shops, picking at the suppliers, in the consolidation center (only in the new system) and consolidation in the consolidation center in the new system.

\subsubsection{Administration}

Last process group is administration. Administration tasks are present at the suppliers, in the consolidation center (only in the new system), at the logistics areas of the shopping malls (cross docks in the new system) and in the shops. 


\subsection{Cost centers in the system}

One of the most important task in the mathematical modelling is to appropriately define the cost centers. First, we tried to work only with junctions, but there are several costs that cannot be assigned to a junction, like the deliveries or the material handling between the logistics areas of the malls and the shops. Therefore, we worked with a graph which shows us every cost center. So, the axis of cost centers in the threedimensional matrix is actually the mapping of a graph with the junctions and connections (roads and material handling routes). This graph for the current logistics system of the shopping malls in Budapest can be seen on Fig. 3.

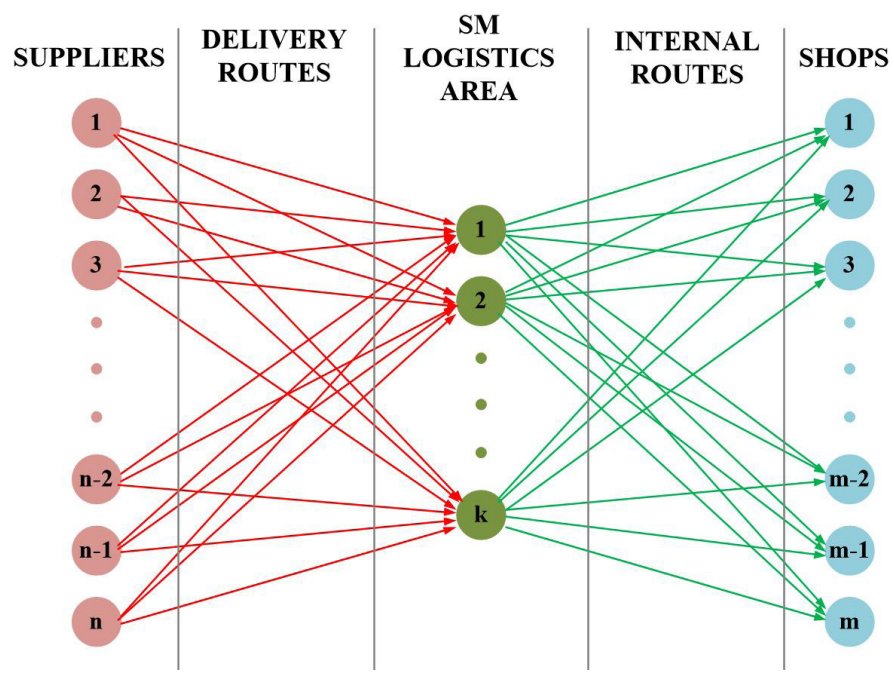

Fig. 3 Graph of the cost centers in the current logistics system of shopping malls

In this graph, we can see every connection as cost centers, but logically there are many of them, where the sum cost is zero, because we do not deliver from every supplier to every logistics area nor do we need to use every internal route in the shopping malls or move goods from every logistics area to every shop. So, the cost centers of the current logistics system:

- $\mathrm{n}$ supplier site

- $n \cdot k$ possible delivery route

- $\mathrm{k}$ logistics area in the shopping mall ( $\mathrm{k}$ is usually between 1 and 5)

- $\mathrm{k} \cdot \mathrm{m}$ possible internal material handling route in the shopping mall

- $\mathrm{m}$ shop in the shopping mall ( $\mathrm{m}$ is usually between 50 and 350).

In the examined system, a company can own many supplier sites, they can use many different delivery routes and they can operate many shops in one shopping mall. So, at one company we can have costs at several different supplier sites, on different delivery routes and in different shops.

The graph of the cost centers in case of the earlier presented new logistics system can be seen on Fig. 4.

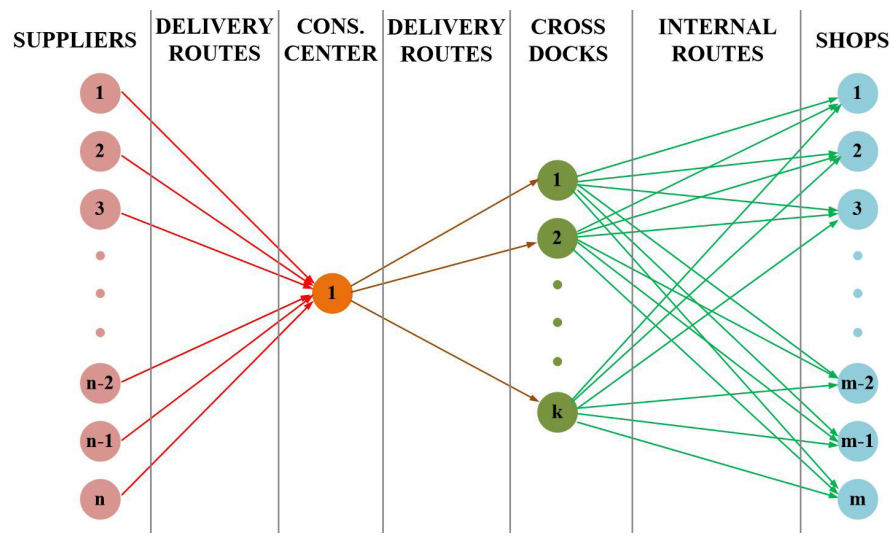

Fig. 4 Graph of the cost centers in the possible future logistics system of shopping malls

In the graph, the connections are defined in the same way as in the current system. So, the cost centers of the new logistics system are the following:

- $\mathrm{n}$ supplier site

- $\mathrm{n}$ possible delivery route between the suppliers and the consolidation center

- consolidation center (in the current study we only have one center, because that is how the simulation model is set up, but naturally this can be changed later)

- $\mathrm{k}$ possible delivery route between the consolidation center and the shopping mall

- $\mathrm{k}$ cross dock in the shopping mall

- $\mathrm{k} \cdot \mathrm{m}$ possible internal material handling route in the shopping mall

- $\mathrm{m}$ shop in the shopping mall.

\subsection{Three-dimensional cost structure}

So, we defined the three dimensions, according to which we are going to analyse the costs: companies, processes and cost centers. The three-dimensional cost structure of the current and the presented new system are illustrated on Fig. 5 and Fig. 6.

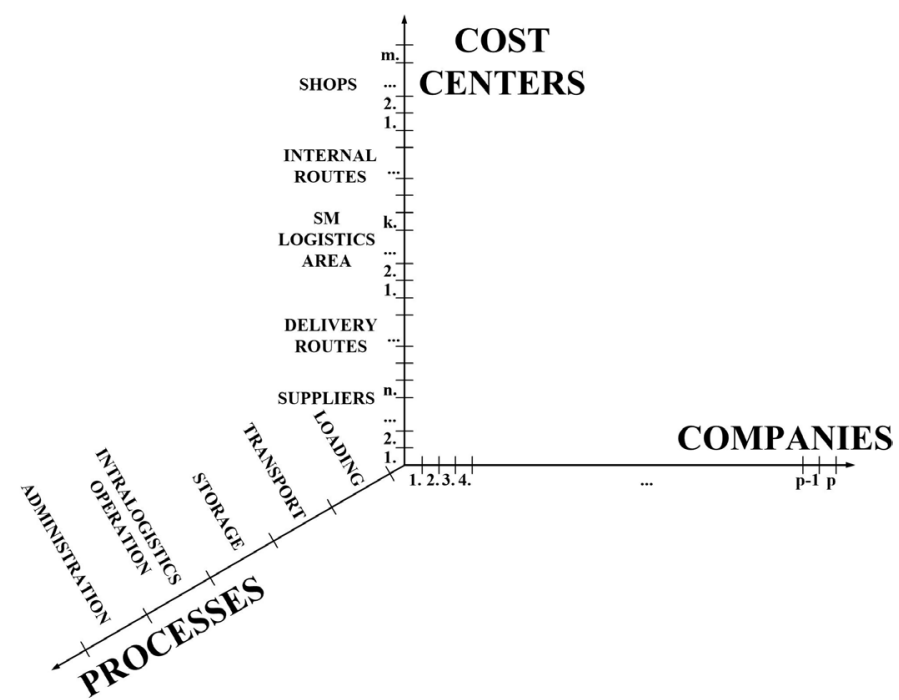

Fig. 5 Three-dimensional cost structure in the current logistics system 


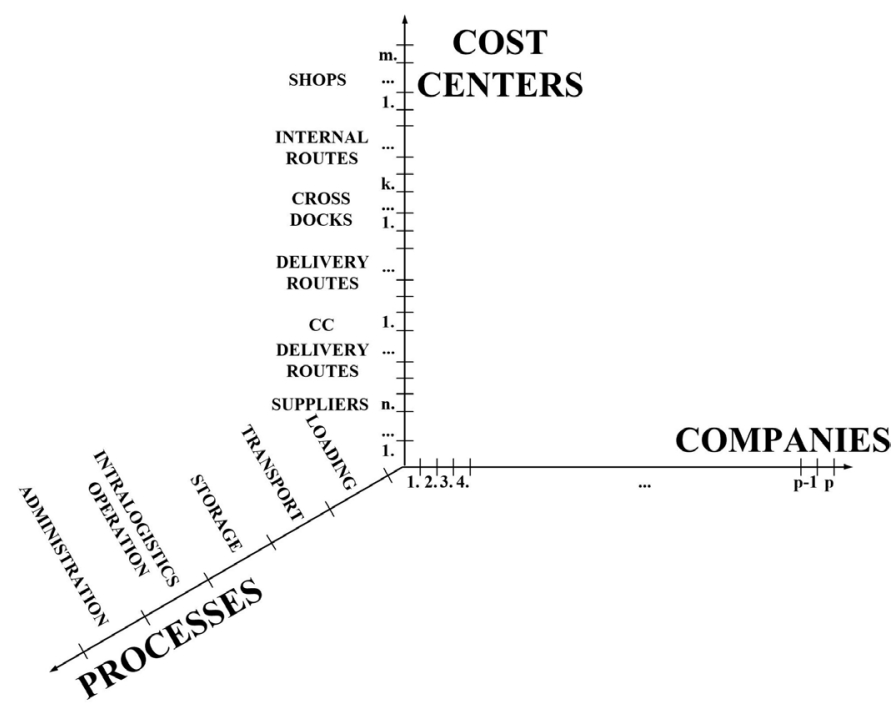

Fig. 6 Three-dimensional cost structure in the possible future logistics system

As an example, on Fig. 7, we can see the storage costs of the shop operator company "i" in a given shopping mall logistics area, indicated with green.

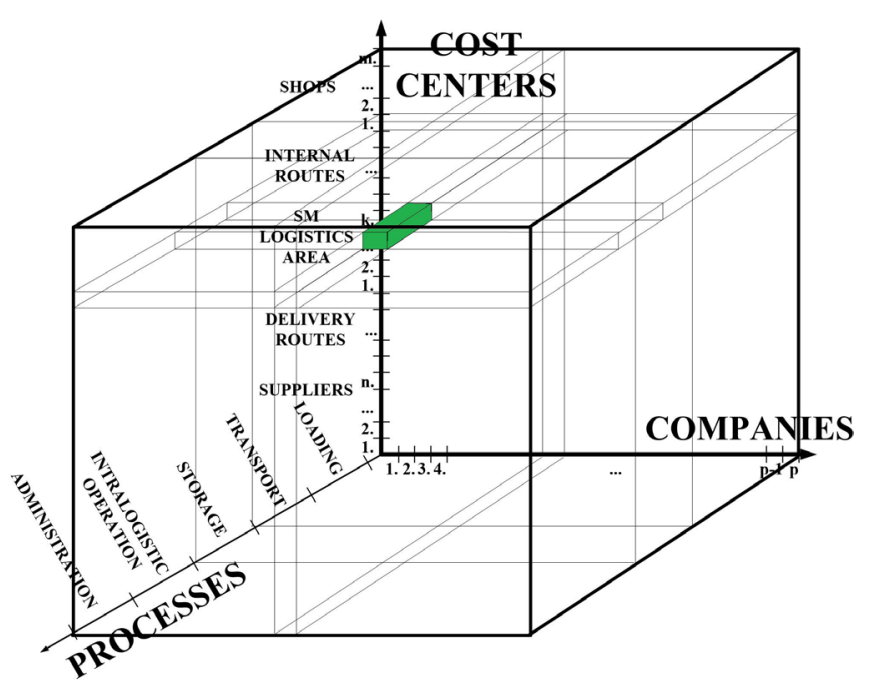

Fig. 7 The cost of a given company in a given cost center in a given process, in the current logistics system

We can see, that the items of the three-dimensional matrix show us the costs of a given company in a given process at a given cost center. This structure covers every possible logistics cost (which are related to the supply system of the shopping malls) of the given companies.

\subsection{Mathematical formulation}

Next step was the mathematical modelling of the cost structure. We formulated the costs by processes. The logic of indexing is the following: first index is always the ID of the processes (L, T, S, I, A), second one is the ID of the companies (in the next formulas we can present the costs of company "i") and the third index is the ID of cost center (in the next formulas we present the costs at cost center " $j ")$. The formulas below are valid for the current and for the new logistics system as well.

\subsubsection{Loading costs}

First one is the loading cost. This one has two main components: the loading and the unloading costs in every case. "Q" is the quantity of goods to be loaded or unloaded (in weight unit), "c" is the specific loading cost (monetary unit/ weight unit). We have loading costs in the supplier sites, in the consolidation center, in the shopping mall and in the shops (and also in the related warehouses). The loading cost of company "i" at cost center "j":

$$
C_{i, j}^{L}=c_{u p_{i, j}}^{L} \cdot Q_{u p_{i, j}}^{L}+c_{d o w n_{i, j}}^{L} \cdot Q_{d o w n_{i, j}}^{L} \cdot
$$

The sum loading cost of company " $\mathrm{i}$ " at " $\mathrm{N}$ " cost center they can use:

$$
C_{i}^{L}=\sum_{j=1}^{N} C_{i, j}^{L}
$$

\subsubsection{Transport costs}

Next one is the transport cost which is present only on the delivery routes. It has two main components, the driving performance-based and the time-based component. The driving performance-based cost has four components: drop-off fee, cost of the loaded tour, cost of the unloaded tour and cost of the invert tour. "N" is the number of delivery transactions, "S" is the distance covered in the given tour (in distance unit), $\mathrm{c}$ is the specific cost (monetary unit/number of tours and monetary unit/distance unit). The driving performance-based transport cost of company "i" on the delivery route "j":

$$
C_{p_{i, b}}^{T}=N_{i, j}^{T} \cdot\left(c_{\text {out }_{i, b}}^{T}+c_{\text {load }_{i, j}}^{T} \cdot S_{\text {load }_{i, j}}^{T}+c_{u n l_{i, j}}^{T} \cdot S_{\text {unl }_{i, j}}^{T}+c_{i n v_{i, j}}^{T} \cdot S_{i n v_{i, j}}^{T}\right) .
$$

In the time-based transport cost, we can see the "c" timebased specific cost (monetary unit/time unit), the " $v$ " average speed and the " $\mathrm{t}_{\mathrm{OP}}$ " operational time (time unit). The time-based transport cost of company "i" on the delivery route "j":

$$
C_{t_{i, b}}^{T}=N_{i, j}^{T} \cdot c_{t_{i, j}}^{T} \cdot\left(\frac{\left.S_{\text {load }_{i, j}}^{T}+S_{u n l_{i, j}}^{T}+S_{i n v_{i, j}}^{T}\right)}{v_{i, j}^{T}}+t_{o p, n_{i, j}}^{T}\right) .
$$

In case of FTL delivery logic, the sum transport cost of company "i" on the delivery route " $\mathrm{j}$ ":

$$
C_{i, j(F T L)}^{T}=C_{F, F T L_{i, j}}^{T}+C_{t, F T L_{i, j}}^{T} .
$$

In case of LTL delivery logic, the sum transport cost of company "i" on the delivery route "j":

$$
C_{i, j(L T L)}^{T}=C_{F, L T L_{i, j}}^{T}+C_{t, L T L_{i, j}}^{T}
$$


The sum transport cost of company "i" on the " $\mathrm{N}$ " delivery route they can use:

$$
C_{i}^{T}=\sum_{j=1}^{N} C_{i, j}^{T}
$$

\subsubsection{Storage costs}

Next are the storage costs. We can define storage costs at the supplier sites, in the consolidation center (only in the new system), in logistics areas of the shopping mall and in the shops (and related warehouses). Storage costs have 5 main components: store in costs, store out costs, storage costs, working capital and order handling costs. In the formula below, "Q" is the quantity of goods to be handled (in weight unit), "c" is the specific cost of the given subprocess (monetary unit/ weight unit), " $\mathrm{n}$ " is the number of order transactions and " $\mathrm{c}_{\text {ord }}$ " is the specific costs of order handling (monetary unit/order). The sum storage cost of company "i" at cost center "j":

$$
\begin{aligned}
& C_{i, j}^{S}=c_{i n_{i, j}}^{S} \cdot Q_{i n_{i, j}}^{S}+c_{o u t_{i, j}}^{S} \cdot Q_{o u t_{i, j}}^{S}+c_{s t_{i, j}}^{S} \cdot Q_{s t_{i, j}}^{S} \\
& +c_{\lambda_{i, j}}^{S} \cdot Q_{s t o r_{i, j}}^{S}+c_{o r d_{i, j}}^{S} \cdot n_{i, j}^{S} .
\end{aligned}
$$

The sum storage cost of company "i" at "N" cost center they can use:

$$
C_{i}^{S}=\sum_{j=1}^{N} C_{i, j}^{S}
$$

\subsubsection{Intralogistics operational costs}

Fourth process group is the intralogistics operation. The main components of the intralogistics operational costs are the manual and machine assisted material handling, picking and consolidation. We define intralogistics operation costs in the supplier sites, in the consolidation center (only in the new system), in the logistics areas of the shopping mall (cross dock in the new system), on the internal routes of the malls and in the shops (or associated warehouses). Picking is not defined in the logistics area of the shopping mall and on the internal routes, consolidation is only defined in the consolidation center. " $\mathrm{T}$ " is the time needed for the given subprocess (in time unit), "c" is the assigned specific cost (monetary unit/time unit). The sum intralogistics operation cost of company "i" at cost center "j":

$$
\begin{aligned}
& C_{i, j}^{I}=c_{\text {hand }_{i, j}}^{I} \cdot T_{\text {hand }_{i, j}}^{I}+c_{\text {mach }_{i, j}}^{I} \cdot T_{\text {mach }_{i, j}}^{I}+c_{\text {pick }_{i, j}}^{I} \cdot T_{\text {pick }_{i, j}}^{I} \\
& +c_{\text {cons }_{i, j}}^{I} \cdot T_{\text {cons }_{i, j}}^{I} .
\end{aligned}
$$

The sum intralogistics operational cost of company "i" at "N" cost center they can use:

$$
C_{i}^{I}=\sum_{j=1}^{N} C_{i, j}^{I} .
$$

\subsubsection{Administration costs}

Last process group is administration which is defined everywhere except delivery routes and internal material handling routes of the mall. Administration consist of goods arriving, goods registration, invoicing etc. In the formula below " $\mathrm{N}$ " is the number of administration tasks and "c" is the assigned specific cost (in monetary unit/administration task). The sum administration cost of company " $i$ " at cost center " $j$ ":

$$
C_{i, j}^{A}=c_{i, j}^{A} \cdot N_{i, j}^{A}
$$

The sum administration cost of company "i" at " $\mathrm{N}$ " cost center they use:

$$
C_{i}^{A}=\sum_{j=1}^{N} C_{i, j}^{A} .
$$

So, we defined the costs in the logistics system of the shopping malls. Based on this, the sum logistics cost of company "i" at cost centers type "k" (for example the sum logistic cost in the shops):

$$
C_{i}^{k}=\sum_{l=L, T, S, I, A} C_{l, i}^{k}
$$

If we summarize them, the sum logistics cost of company "i" in the logistics system of a given shopping mall:

$$
C_{i}=\sum_{k=1}^{K} C_{j, i} .
$$

So, the sum logistics cost of the logistics system of a given shopping mall:

$$
C_{S M}=\sum_{i=1}^{p} C_{i}
$$

Now, we defined the mathematic model of the cost structure of the logistics system of shopping malls, which describes the current and also the possible future system. If we add this model to the mesoscopic simulation model we developed earlier, we can simulate the respective costs of the current and proposed systems allowing us to draw comparisons between them.

\section{Numerical example}

The mesoscopic simulation model which was developed $n$ MS Excel has two main components. The first one simulates the processes of the current system, the second one the possible future system with a consolidation center and cross docks. The two components are similar, and they use identical input data. The model calculates the time of delivery and delivered quantity by use of random generators based on the input data. Based on this it calculates the parameters of the deliveries, consumption, emission and material handling needed, it models the inventory points of the system and calculates the number of deliveries needed in the new system 


\begin{tabular}{|c|c|c|c|c|c|c|c|c|c|c|}
\hline \multicolumn{11}{|c|}{ 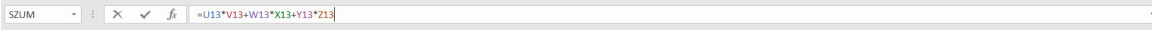 } \\
\hline 4 & A & B & c & D & w & $\mathrm{x}$ & $\mathrm{r}$ & z & AA & $A B$ \\
\hline 1 & \multirow{2}{*}{\multicolumn{4}{|c|}{ Transport informations }} & \multirow{2}{*}{\multicolumn{4}{|c|}{ Intralogistical operation costs }} & & \\
\hline 2 & & & & & & & & & & \multirow{2}{*}{$\frac{\text { Admi }}{\mathrm{N}(\mathrm{adm})[\mathrm{pc}}$} \\
\hline 3 & Mall ID & Supplier ID & Shop ID & SKU ID & $\mathrm{T}(\mathrm{mh}, \mathrm{mach})[\mathrm{min}]$ & $\mathrm{c}(\mathrm{mh}, \mathrm{mach})$ & $\mathrm{T}$ (pick) [min] & c(pick) & C(intra) & \\
\hline 4 & SM001 & SUP0001 & SH0001 & SKU006 & 75 & 17,35 & 0 & 0 & 1301,25 & \\
\hline 5 & SM001 & SUP0002 & SH0002 & SKU005 & 56 & 17,91666667 & 0 & 0 & \begin{tabular}{|l|l|}
0 & 1003,333333 \\
\end{tabular} & \\
\hline 6 & SM001 & SUP0003 & SH0003 & SKU003 & 80 & 18,11666667 & 0 & 0 & \begin{tabular}{|l|l|}
0 & 1449,333333 \\
\end{tabular} & \\
\hline 7 & SM001 & SUP0004 & SH0004 & SKU002 & 676 & 18,11666667 & 0 & 0 & \begin{tabular}{l|l|}
0 & 12246,86667 \\
\end{tabular} & \\
\hline 8 & SM001 & SUP0005 & SH0005 & SKU002 & 45 & 15,78333333 & 0 & 0 & 710,25 & \\
\hline 9 & SM001 & SUP0006 & SH0006 & SKU006 & 60 & 16,91666667 & 0 & 0 & 1015 & \\
\hline 10 & SM001 & SUP0007 & SH0007 & SKU006 & 140 & 15,9 & 0 & 0 & 2226 & \\
\hline 11 & SM001 & SUP0008 & SH0008 & SKU003 & 869 & 17,316666667 & 0 & 0 & \begin{tabular}{|l|l|} 
& 15048,18333 \\
\end{tabular} & \\
\hline 12 & SM001 & SUP0009 & SH0009 & SKU003 & 90 & 15,5 & 0 & 0 & 1395 & \\
\hline 13 & SM001 & SUP0010 & SH0010 & SKU003 & 325 & 16,13333333 & 0 & & $0=\mathrm{U} 13 * \mathrm{~V} 13+\mathrm{W} 1$ & \\
\hline 14 & SM001 & SUP0011 & SH0011 & SKU001 & 864 & 16,38333333 & 0 & 0 & 14155,2 & \\
\hline 15 & SM001 & SUP0012 & SH0012 & SKU001 & 1629 & 16,51666667 & 0 & 0 & 26905,65 & \\
\hline 16 & SM001 & SUP0013 & SH0013 & SKU003 & 195 & 16,21666667 & 0 & 0 & 3162,25 & \\
\hline
\end{tabular}

Fig. 8 The cost-calculator worksheet of the simulation model

(Sárdi and Bóna, 2017). We added to this simulation model the mathematical model of the cost structure. The cost calculator worksheet of the simulation model can be seen on Fig. 8 .

\subsection{Specific costs}

In our earlier research, we were not able to get information about specific costs, we collected only performance data. We detailed the problems of collection of cost data earlier in chapter 2 , but we needed this data for the simulation to calculate the logistics costs of the system. Because of this, we had to estimate the specific costs. Estimation was based on the experience of logistics specialists and also the documentations and bids of former logistics projects. In the simulation, the specific costs of the current system's processes and also the specific costs of the processes which are handled by the shop operator companies in the new system, were randomly generated between a lower and an upper specific cost limit. In the new system, the specific costs of the processes which are handled by the city logistics provider (who operates the consolidation center and the cross docks) were given as constants, in the model these costs are paid by the shop operators as fixed cost to the logistics provider. In the current research, we did not examine the costs of picking, the inventory in the logistics area (or cross dock), the shopping malls and the working capital, because we did not have enough data about them. We handled the deliveries in every case as FTL organized deliveries, because it was the predominant method in the processes observed.

\subsection{Simulation and results}

Simulation was based on the data of 178 shops of 3 shopping malls; these were the data series that have no important data missing. Simulation runs were performed with $95 \%$ reliability and $5 \%$ allowed error.

The first task was to validate the simulation models. We compared the two modelled system based on the weight of goods to be delivered. There is no significant difference between the expected value of the weight, it is around $1350 \mathrm{t} /$ month in both case, the difference is only $2 \%$ which is due to the small differences between the random generators. Based on this, the two examined systems are well comparable.
The expected number of monthly delivery transactions (of 178 shops in 3 malls) in the current system is 3399 (standard deviation 14). In contrast, in the new system there are 1343 deliveries (standard deviation 17) between the suppliers and the consolidation center and there are 265 monthly deliveries (standard deviation 6) between the center and the malls, so we can reduce the sum number of deliveries by $53 \%$ in the new system and the sum number of deliveries in the city by $92 \%$. The change of parameters of driving and delivery performance can be seen on Fig. 9.

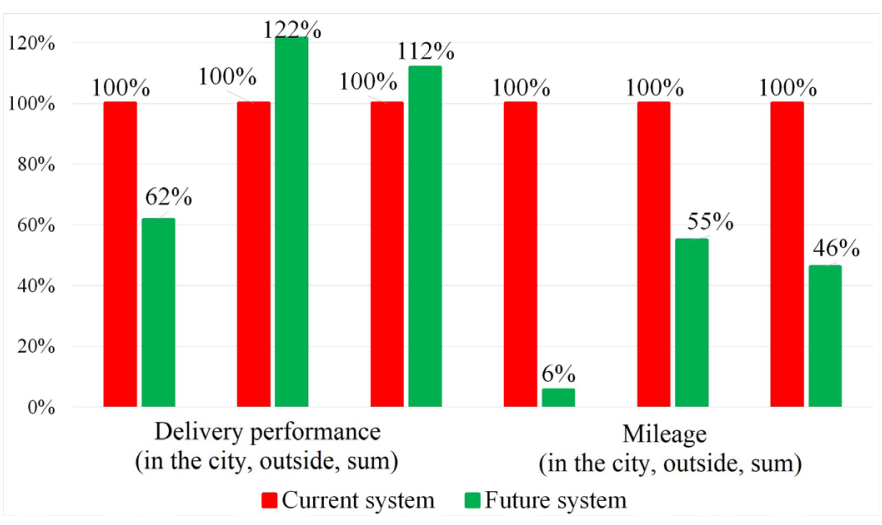

Fig. 9 Delivery performance and mileage in the current system and in the possible future system

In the simulation, cars were handled as petrol powered, lorries and trucks as diesel powered (Hungarian Central Statistical Office, 2014). The petrol consumption in the two systems is similar (763 1/month, 876 1/month), but the diesel consumption can be reduced by approximately $8000 \mathrm{l} /$ month in the new system (current: $183331 /$ month, $76981 /$ month), which is a significant amount that also leads to substantial reduction of emission. Based on the results of the simulation, the emission of the examined pollutants $\left(\mathrm{CO}, \mathrm{CO}_{2}, \mathrm{HC}, \mathrm{NO}_{\mathrm{x}}, \mathrm{PM}\right)$ can be reduced by more than $50 \%$ in every case by use of the new city logistics system which uses a consolidation center and cross docks.

Taking all examined costs into account, the expected amount of the sum logistics costs in the current system is 79.127 .175 $\mathrm{Ft} /$ month (standard deviation 2.340.454 Ft). The largest chunk is the costs of the delivery transactions, which makes up more 
than $75 \%$ of the total monthly costs. The costs in the supplier sites and in the shops are also significant because of the loading costs and storage costs.

In the new system the expected total of the aggregated logistics costs is $58.918 .832 \mathrm{Ft} /$ month (standard deviation 1.272.727 Ft). The transport costs are significant here too, but they are decreased by 27 million Ft/month. The second biggest fraction here is the costs of the consolidation center, it is approximately 9 million $\mathrm{Ft} /$ month. Other costs do not change significantly in the new system, so the total monthly logistics costs can be reduced by 20 million Ft, by use of a consolidation center in case of 178 shops in 3 shopping malls. The costs in the two systems can be seen on Fig. 10.

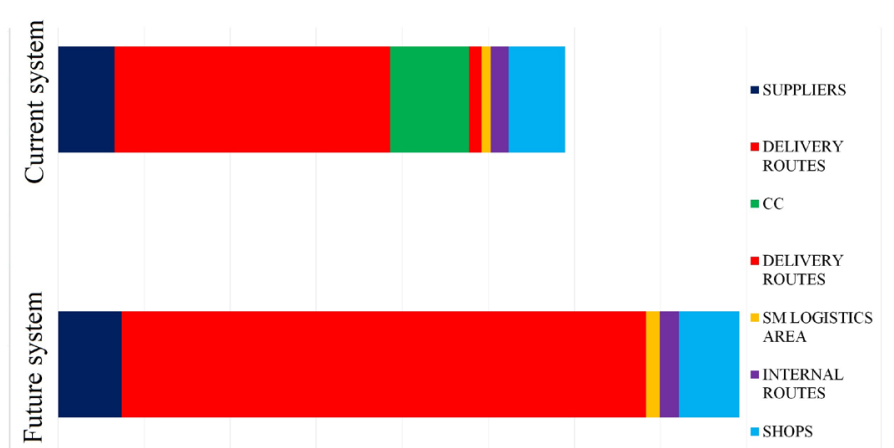

$\begin{array}{lllllllll}0 & 10 & 20 & 30 & 40 & 50 & 60 & 70 & 80\end{array}$ [million HUF]

Fig. 10 Monthly logistics costs in the current and in the future logistics system of the shopping malls

These results show us that the proposed system leveraging consolidation and cross docks could reduce the logistics costs significantly. Now, we neglected some subprocesses, so their costs might influence the results slightly, but we also did not examine the external costs. We did not quantify the financial effects that the reduction of loads on the city's roads, reduction of noise pollution and reduction of emission mean. The costs and macroeconomic effects of road (freight and also passenger) transport are a very important area in EU and also in Hungary (Török and Török 2014), there are several related researches and hopefully our results can have an important role in this area.

Therefore, we can say that based on the results of our simulation runs, this kind of new, multi-stage city logistics system has substantial potential in terms of cost reduction.

\section{Conclusion}

Now, after the data collection and modelling, we have a complex mesoscopic simulation model which makes it possible to examine the logistics processes between the inventory point of suppliers and the shops in the shopping malls by performance and costs. Earlier we had no means to examine the costs in this model as well, but now we are able to comprehensively examine the entire logistics system of shopping malls in Budapest due to the addition of the discussed cost structure to our simulation model.
The mathematical model of the cost structure was formulated by process groups (loading, transport, storage, intralogistics operation, administration) for the current logistics system and for a new system with a consolidation center and cross docks.

We can say that the mathematical modelling and the simulation modelling was an important step in our research project, but there are several other tasks to be solved. It is important to add the inverse logistics processes to the model. We would like to perform sensitivity analysis to examine the change of specific costs and we would like to perform the simulation using real cost data. In this step, we developed a linear mathematical model, but in the next steps we would like to examine also the nonlinear connections between the performance and costs.

Our main result is now a tool which makes it possible to compare the performances and the costs of the current and the possible future logistics systems in shopping malls. In the next years, this tool could have an important role in the planning phase of new city logistics systems, by making it possible to examine the costs of the new system before the realization and this can serve as a basis for several important decisions.

\section{Acknowledgement}

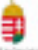

Excellence Program of The Ministry of Human Capacities.

\section{References}

Bakos, A., Bóna, K., Foltin, Sz. (2012). The development of a complex city logistics cost model according to a multiple-stage gateway concept. Periodica Polytechnica Transportation Engineering. 40(1), pp. 17-20. https://doi.org/10.3311/pp.tr.2012-1.03

Bakos, A. (2013). Budapesti áruellátási, city logisztikai tervváltozatok összehasonlítása költségmodell alapján. (Comparison of city logistics plans in Budapest based on cost model.) Magyar Logisztikai Egyesület Logisztikai Évkönyv 2013. pp. 13-17. (in Hungarian)

Bokor, Z. (2006). A logisztikai költségszámítás korszerüsítése kontrolling eszközökkel. (Modernization of the logistics cost calculation by us of controlling methods.) Magyar Logisztikai Egyesület Logisztikai Évkönyv 2006. pp. 41-49. (in Hungarian)

Bokor, Z. (2006). Kontrollingmódszerek alkalmazása a logisztikában. (Controlling methods in logistics.) In BME OMIKK LOGISZTIKA 11. k. 2. sz. 2006. március-április. pp. 07-26. http://www.omikk.bme.hu/ collections/mgi_fulltext/logisztika/2006/02/0205.pdf (in Hungarian)

Bokor, Z. (2010). Cost drivers in transport and logistics. Periodica Polytechnica Transportation Engineering. 38(1), pp. 13-17. https://doi.org/10.3311/pp.tr.2010-1.03

Bokor, Z. (2011). Calculation model for transport costing. Periodica Polytechnica Transportation Engineering. 39(1), pp. 43-47. https://doi.org/10.3311/pp.tr.2011-1.08

Bokor, Z. (2012). Cost calculation model for logistics service providers. Promet Traffic\&Transportation. 24(6), pp. 515-524. https://doi.org/10.7307/ptt.v24i6.1198

Duma, L. (2008). A logisztikai teljesítménymérés kérdései a hálózatosodó gazdaságban. (Logistics performance measurement in the networking economy.) Magyar Logisztikai Egyesület Logisztikai Évkönyv 20072008. pp. 47-53. (in Hungarian) 
Griful-Miquela, C. (2001). Activity-Based Costing Methodology for ThirdParty Logistics Companies. International Advances in Economic Research. 7(1), pp. 133-146. https://doi.org/10.1007/BF02296598

Grzybowska, K., Kovács, G. (2016). The modelling and design process of coordination mechanisms in the supply chain. Journal of Applied Logic. 24, pp. $25-38$.

https://doi.org/10.1016/j.jal.2016.11.011

Hungarian Central Statistical Office (2014). Gépjármüállomány Magyarországon üzemanyagtípus szerint az adott év december 31-én. (Vehicle fleet in Hungary by used fuel on the 31. of December of the given year.) (in Hungarian) [online] Available from: www.ksh.hu/docs/ hun/xftp/idoszaki/jelszall/jelszall14.xls [Accessed: 31st January 2018]

Hungarian Central Statistical Office (2015). The number of retailers in Budapest. [online] Available from: http://www.ksh.hu/docs/hun/xstadat/ xstadat_evkozi/e_okk012.html [Accessed: 31st January 2018]

Mészáros, B., Sárdi, D., Bóna, K. (2016). Developing and testing a methodology for acquiring the logistical characteristics of shopping malls in Budapest, for city logistical solutions. In: 5th IEEE International Conference on Advanced Logistics and Transport. Krakow, Poland, 2016. pp. 154-159.
Mészáros, B., Sárdi, D. Bóna, K. (2017). Monitoring, measurement and statistical analysis (MMSA) based methodology for improvement city logistics of shopping malls in Budapest. World Review of Intermodal Transportation Resarch. 6(4), pp. 352-371.

https://doi.org/10.1504/WRITR.2017.10009827

Sárdi, D., Bóna, K. (2017). Developing a mesoscopic simulation model for the examination of shopping mall freight traffic in Budapest. In: Smart Cities Symposium 2017. Prague, https://doi.org/10.1109/SCSP.2017.7973835

Śliwczyński, B. (2011). Operational controlling - a tool of translating strategy into action. LogForum Scientific Journal on Logistics.7(1), pp. 45-59. https://www.researchgate.net/publication/267839738

Török, Á., Török, Á. (2014). Macroeconomic analysis of road vehicles related environmental pollution in Hungary. Central European Journal of Engineering. 4(2), pp. 186-191.

https://doi.org/10.2478/s13531-013-0147-0 